\title{
David Oliver: From acute ward to care home-a journey fewer should take?
}

\author{
David Oliver consultant in geriatrics and acute general medicine
}

Berkshire

NHS hospitals increasingly treat, in acute or subacute crisis, our oldest citizens, often those with multimorbidity, frailty, and dementia. $^{12}$

Some are serially readmitted when it's too challenging to assess them at home, each crisis damaging our confidence, and theirs, about staying at home. Others have life changing events such as stroke or hip fracture, bringing new disability. Some will transition straight from that acute admission into a new care home placement, waving their former home goodbye. ${ }^{3}$

It's pointless being rigidly proscriptive or prescriptive about this unfortunate scenario. It can't be a "never" event. ${ }^{4}$ Sometimes it's the best or only option left, what patients freely choose, the only option now acceptable to exhausted carers, or where careful best interest decisions lead.

Yet we could do more to make this less common. Sixfold geographical variations in new care home placements, including those from acute hospitals, are not accounted for by population need. ${ }^{56}$ So, what might help, once patients have already made it beyond the hospital front door or community responses?

We need to do all we can to establish reliable, early, proactive rehabilitation and ensure that admission doesn't make patients more dependent, institutionalised, and harder to get back home-for example, from preventable or undiagnosed delirium, poor nutrition, or functional loss.?

Multidisciplinary, ward based comprehensive geriatric assessment (CGA) improves patients' chances of remaining alive and at home months after leaving hospital. ${ }^{89}$ Ideally, we'd ensure that no decisions or promises were made without this. Giving geriatricians care home forms to complete, when the decision is a fait accompli, helps nobody.

Common causes of new care home admissions include incontinence, falls, immobility and dependence, dementia, and associated behavioural and psychological symptoms. ${ }^{10}$

Giving geriatricians care home forms to complete, when the decision is a fait accompli, helps nobody
CGA can help identify these problems, reverse the reversible, or develop plans to help people and their carers live better with the irreversible. But, unless we reverse the severe rationing of home care services and continuing care funding, the offer of home support will often still be inadequate. ${ }^{11}{ }^{12}$

Better access to age-friendly and extra-care housing, adjustments to existing properties, and telecare could also support more people at home for longer. ${ }^{13}{ }^{14}$ Crucially, we need more capacity in step-down intermediate care or "time to decide" services and beds, to give every chance of less rushed recovery outside acute ward settings. ${ }^{15}$

Finally, we must resist pressure from full beds or well meaning families to make hasty, pressurised, life changing decisions when people are still recovering. Older citizens have the same right to take risks as the rest of us. We shouldn't make infantilising and ageist decisions about them without them, however well intentioned.

1 NHS Confederation. Growing old together: sharing new ways to support older people. 2016. www.nhsconfed.org/ /media/Confederation/Files/Publications/Documents/Growing\% 20old\%20together\%20-\%20report.pdf.

2 Oliver D, Foot C, Humphries R. Making our health and care systems fit for an ageing population. King's Fund 2014. https://www.kingsfund.org.uk/sites/files/kf/field/field_ publication_file/making-health-care-systems-fit-ageing-population-oliver-foot-humphriesmar14.pdf.

3 National Audit Office. Discharging older people from hospital. 2016. https://www.nao.org. uk/wp-content/uploads/2015/12/Discharging-older-patients-from-hospital.pdf.

4 Oliver D. Admission to a care home can never be a "never" event. King's Fund blog 28 Aug 2014. https://www.kingsfund.org.uk/blog/2014/08/admission-nursing-home-can-neverbecome-never-event.

5 Public Health England. NHS England. The NHS atlas of variation in healthcare (map 63). See 2015 version at: http://fingertips.phe.org.uk/profile/atlas-of-variation.

6 Audit Commission. Joining up health and social care: improving value for money across the interface. Dec 2011. www.cardiffandvaleuhb.wales.nhs.uk/sitesplus/documents/1143/ Value\%20for\%20Money\%20through\%20Integration\%20Audit\%20Commission.pdf. Oliver D. David Oliver: Frailty in acute care. BMJ 2016;357:i5195. doi:10.1136/bmj. i5195 pmid:27686650.

8 Ellis G, Whitehead MA, O'Neill D, Langhorne P, Robinson D. Comprehensive geriatric assessment for older adults admitted to hospital. Cochrane Database Syst Rev 2011;357:CD006211.pmid:21735403.

9 British Geriatrics Society, Royal College of Physicians, Royal College of Nursing, et al. "Silver book": quality care for older people with urgent and emergency care needs. 2012. www.bgs.org.uk/campaigns/silverb/silver_book_complete.pdf.

10 British Geriatrics Society. Quest for quality. 2011 www.bgs.org.uk/campaigns/carehomes/ quest_quality_care_homes.pdf. 
11 King's Fund, Nuffield Trust. Social care for older people: home truths. Sept 2016. https:/ /www.kingsfund.org.uk/sites/files/kf/field/field_publication_file/Social_care_older_people Kings_Fund Sep_2016.pdf.

12 Oliver D. David Oliver: NHS continuing care is a mess. BMJ 2016;357:i4214. doi:10.1136/ bmj.i4214 pmid:27495806.

13 National Housing Federation. On the pulse: housing routes to better health outcomes for older people. Jun 2012. www.housinglin.org.uk/_assets/Resources/Housing/

OtherOrganisation/OnThePulse.pdf.
14 LIN Housing. Care and support in housing with care for older people: policy technical brief. 27 Oct 2015. www.housinglin.org.uk/Topics/type/Care-and-Support-in-Housing-withCare-for-Older-People-Policy-Technical-Brief/.

15 NHS Benchmarking. National Audit of Intermediate Care summary report. 2015. www. nhsbenchmarking.nhs.uk/CubeCore/.uploads/NAIC/Reports/ NAICReport2015FINALA4printableversion.pdf.

Published by the BMJ Publishing Group Limited. For permission to use (where not already granted under a licence) please go to http://group.bmj.com/group/rights-licensing/ permissions 